\title{
Språkspalten er 25 år
}

\section{1990 ble Tidsskriftets språkspalte lansert. Jubileet markeres med etableringen av en gruppe for norsk medisinsk fagspråk.}

«Tidsskriftet står sentralt i utviklingen av et norsk medisinsk språk. Som et uttrykk for dette, oppretter vi i dette nummeret en språkspalte», skrev redaktør Magne Nylenna ved etableringen i 1990 (1). Initiativet var vellykket, spalten lever i beste velgående.

En gjennomgang av de første 20 årene viste at bidragene var svært varierte (2). Det samme kan sies også om den seneste femårsperioden. Vi har beveget oss høyt og lavt i den språklige geografien, 120 bidrag er blitt publisert og engasjementet har vært stort.

Flere innlegg har dreid seg om å finne gode norske avløserord, for eksempel oppmerksomt nærvær (mindfulness), balansediagram (forest plot), ventesorg (anticipatory grief), viftediagram (fan chart), grøftegraverfraktur (clay-shoveler's fracture), sykdom på fremmarsj (emerging disease), ikke-underlegenhetsstudier (non-inferiority studies), røvertidsskrifter (predatory journals), sykdomssalg (disease mongering) og sammenliknende effektforskning (comparative effectiveness research).

I flere artikler har man drøftet problemord, som forskrive/foreskrive, henspille (ikke «henspeile»), sjeflege/sjefslege, kanyle/kateter, opiat/opioid osv. Ordhistorie har også vært tema i flere tekster: kverulering, vitamin, influensa, delirium, lasarett, betablokkere, karantere, pruritus, emeritus, uhelse, optimalt, cave, akademia, biotilsvarende legemidler etc. Mest debatt ble det om moteord, klisjeer og svada.

Hva med å gjenoppfriske noen av temaene - eller kanskje lese dem for første gang? Alle artiklene ligger fritt tilgjengelig på internett. På nettsiden http://tidsskriftet.no/ articlesearch kan du skrive «Språkspalten». Dersom du ønsker en kronologisk oversikt, klikker du på «dato».

\section{Gruppe for medisinsk fagspråk} I jubileumsåret har vi opprettet en gruppe for norsk medisinsk fagspråk. I det første møtet diskuterte vi hva verbet av ruptur bør hete: rumpere, ruptere eller kanskje rupturere? Og bør coronavirus skrives med c eller k? Svar følger i kommende utgaver av Tidsskriftet.

Gruppen består av Tidsskriftets sjefredaktør, Tidsskriftets manusredaktører samt medisinsk redaktør Petter Gjersvik, språkspalteredaktør Erlend Hem, direktør i Nasjonalt kunnskapssenter for helsetjenesten og ordbokredaktør Magne Nylenna og tidligere manusredaktør Raida Ødegaard.

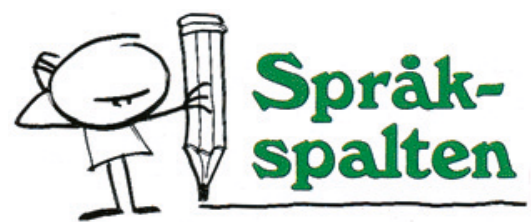

Vignetten som ble brukt de første årene

Følg med og bidra gjerne! Intet språklig er Språkspalten fremmed.

\section{Erlend Hem}

erlend.hem@medisin.uio.no

Erlend Hem (f. 1970) er dr.med., fagsjef i Klinikk psykisk helse og avhengighet, Oslo universitetssykehus og redaktør for Tidsskriftets språkspalte.

\footnotetext{
Litteratur

1. Nylenna M. Språkspalten. Tidsskr Nor Lægeforen 1990; 110: 1871

2. Hem E. Språkspalten er 20 år! Tidsskr Nor Legeforen 2010; 130: 1373
} 